\title{
ENDOWMENT AND WAQF FUNDS IN MALAYSIAN HIGHER EDUCATION: A CONCEPTUAL STUDY
}

\author{
Nurul Adilah Hasbullah ${ }^{1}$ \\ Asmak Ab Rahman²
}

\begin{abstract}
Higher Education Institutions (HEIs) require sustainable sources of income to fund operating costs. The role of endowment funds has always been significant in providing financial sources to these institutions. In Islam, an endowment is known as waqf. As the differences in these two types of funds are found to be indistinctive, this study explores and highlights the atypical concepts. The method of library research has been used to acquire relevant reference materials to discuss the concepts. This paper has identified several aspects that distinguished these two funds, which include the element of perpetuity element, rights of ownership, and governance (law, structure, trustee, need permission, and income sharing).
\end{abstract}

Keywords: endowment, waqf, higher education, Malaysia

1 Ph.D. Candidate, Department of Shariah and Economics, Academy of Islamic Studies, University of Malaya, 50603 Kuala Lumpur, Malaysia,n.adilahasbullah@, perdana.um.edu.my

2 Associate Professor, Department of Shariah and Economics, Academy of Islamic Studies, University of Malaya, 50603 Kuala Lumpur, Malaysia, asmak@um.edu. my 


\section{INTRODUCTION}

More than $90 \%$ of the expenses by public universities in Malaysia have primarily depended on government funds, ${ }^{3}$ which is considerably high. Hence, the government has consistently sought to reduce these funds by giving autonomy power to the universities to source for funds. The autonomous power given requires the university to earn $30 \%$ of the income, as highlighted by Amran and Muhammad. ${ }^{4}$ This initiative is consistent with the plan of Ministry of Education Malaysia (MoE) under the Malaysia Education Blueprint 20152025 (Higher Education), also known as the MEB (HE), as an effort to reduce the dependence of HEI on the government. Also, the fifth agenda in the MEB plan that emphasises financial sustainability encourages HEIs in Malaysia to seek additional income sources as an alternative to become more flexible, more reliable, and more sustainable in terms of institutional finances.

Besides the tuition fees imposed on students as private financial sources, voluntary donations from third parties have also been an alternative for HEIs to obtain additional resources of income. Pérez-Esparrells and Torre have argued that voluntary donations can be considered as the primary fundraising income stream for most institutions. ${ }^{5}$ Proven based on results from studies in the United States (U.S.), this type of financial support provides a massive contribution towards HEIs, which has accumulated about $\$ 49.60$ billion in 2019. This amount has been increased by 6.1 per cent compared to the amount in 2018 (\$46.73 billion), which is reported to be the at highest ever through the Voluntary Support of Education (VSE) Survey conducted by the Council for Advancement and Support of Education (CASE). ${ }^{6}$

According to Johnstone, several methods can be used to manage voluntary donations in HEIs, such as through endowments, gifts, or redistribution of tuition fees (some students can pay less because of financial surplus by more

3 The University Transformation Programme (UniTP) Purple Book: Enhancing University Income Generation, Endowment \& Waqf (Putrajaya: Kementerian Pendidikan Tinggi Malaysia, 2016), 7.

4 A. Amran \& J. Muhammad, 'Changes and Challenges in Financial Autonomy,' in Governance Reforms in Public Universities of Malaysia, ed. F. Md. Taib \& M. N. L. Y. Abdullah (Pulau Pinang: Penerbit Universiti Sains Malaysia, 2015), 66.

5 Carmen Pérez-Esparrells \& Eva M. Torre, 'The Challenge of Fundraising in Universities in Europe,' International Journal of Higher Education, vol. 1/2 (2012): \\r|\nbut also new means of raising supplementary philanthropic (private57.

6 'Voluntary Support of Education' (London, Mexico City, Singapore \& Washington, D.C., 2020), 4. 
affluent students). ${ }^{7}$ Voluntary donations in the form of endowments would be the main focus in this study, specifically waqf, which is considered as an endowment from the perspective of Islam. The Ministry of Higher Education (MoHE) Malaysia has supported the implementation of these two types of funds (endowment and waqf) in the HEIs within Malaysia through the publication of Purple Book ${ }^{8}$ and Panduan Pengurusan Wakaf: Institusi Pendidikan. ${ }^{9}$ These books contain guidance for public universities to enhance the generation of income through endowment and waqf funds.

Since then, the number of public universities that implement endowment and waqf funds has increased. According to the Department of Higher Education (Malaysia), all public universities have implemented the endowment fund until 2019, with 17 of these universities have implemented the waqf funds. ${ }^{10}$ This result shows that public universities in Malaysia have positively responded to the recommendations by the government. Other universities that have yet to implement any of these funds indicated that the knowledge of these funds has been quite limited. Therefore, discussions on these funds, especially on the concepts involved should be provided as exposure for these universities. At the same time, this study can also help these universities identify the similarities and differences in deciding to choose (or both) the most suitable option. Since the discussion about the concept is extensive, this study has chosen to focus only on several aspects, which are definition, philosophy of giving, types, elements, and governance. A discussion about each aspect can be found in the following sections.

\section{DEFINITION OF ENDOWMENT AND WAQF FUNDS}

Based on the New International Webster's Comprehensive Dictionary of the English language, 'endow' is defined as to bestow a permanent fund or

7 D. Bruce Johnstone, Financing Higher Education: Cost-Sharing in International Perspective (The Netherlands: Sense Publishers, 2006), 39.

$8 \quad$ The University Transformation Programme (UniTP) Purple Book: Enhanching University Income Generation, Endowment \& Waqf (Putrajaya: Kementerian Pendidikan Tinggi Malaysia, 2016).

9 Panduan Pengurusan Wakaf Institusi Pendidikan (Putrajaya: Jabatan Wakaf, Zakat dan Haji (JAWHAR), 2018).

10 Mohamad Afizal Mehat, (Senior Assistant Director, Department of Higher Education (Malaysia), Public HEI Governance Division), data gained through e-mail, 9 February 2020. 
income. ${ }^{11}$ Meanwhile, the Dictionary of Contemporary English has defined 'endowment' as a certain amount of money someone gives to a school, a college or other institutions, which encompasses the act of giving money. ${ }^{12}$ Moreover, 'permanent' can be interpreted through the New International Webster's Comprehensive Dictionary on an endowment, which is money or property given to an institution, person or object for permanent use. ${ }^{13}$ From the perspective of scholars such as Sazonov, Kharlamova, Chekhovskaya, and Polyanskaya, an endowment can also voluntary donations to legal entities and individuals, which consist of an untouchable part to be invested in financial assets and is a guarantee of the availability of money assets in the future. Meanwhile, income from investments of the principal sum of the target capital can be spent. ${ }^{14}$ Moreover, Ehrenberg has defined endowment from the standpoint of education institution as financial and real estate stocks that are held by universities to generate income for both current and future operations. ${ }^{15}$

In Islam, a fund created for continuous usage is known as waqf, a word that is originated from the Arabic word, waqafa, which means holding (al-habs) or preventing (al-man ), as described by al-Sarakhsī. ${ }^{16}$ Although there are two literal meanings of waqf, fiqh scholars such as al-Nawawī, Ibn Qudāmah, and Ibn 'Ābidīn have collectively agreed to define waqf according to the term of al-

11 The New International Webster's Comprehensive Dictionary of The English Language, Deluxe Enc (Naples, Florida: Trident Press International, 1996), 419, entry 'endow'.

12 Dictionary of Contemporary English, 4th ed. (England: Pearson Education Limited, 2003), 516, entry 'endowment'.

13 The New International Webster's Comprehensive Dictionary of The English Language, 419, entry 'endowment'.

14 Sergey Sazonov, Ekaterina Kharlamova, Irina Chekhovskaya, \& Elena Polyanskaya, 'Funds on the Basis of Mathematical Models Mechanism of Determination of Effectiveness of Spending Assets of Endowment Funds on the Basis of Mathematical Models,' International Journal of Educational Management, vol. 31/1 (2017): 22.

15 Ronald G. Ehrenberg, 'Demystifying Endowments,' 2009, see http:// digitalcommons.ilr.cornell.edu/ workingpapers/132/\%0ARequired., 2, accessed on 9 March 2020.

16 Al-Sarakhsī, Abū Bakr Muhammad Shams al-Dīn, al-Mabsūṭ, vol. 12 (Bayrūt: Dār al-Kitāb al-'Alamiyah, 2001), 34. 
habs to be associated with the shara ' definition. ${ }^{17}$ Jumhūr 'ulamā' have defined waqf as a holding property, which can be benefited from the preserved 'ayn, whereby when a donor donates his property to the waqf fund, his ownership of the waqf property is eliminated. Based on this description, a person who practices waqf not only focuses on charity but also as a commendation to Allah SWT, as described by al-Hammam; al-Khatib; and al-Rahaybanī. ${ }^{18}$ AlZuhayli further clarifies that the property under waqf no longer belongs to the waqf donor, and instead, would be established under the hukm of Allah SWT, with the benefits being distributed to charity as suited to the purpose of waqf. ${ }^{19}$ According to Nazị Hammād, this definition encompasses the meaning to restrain property and distribute the benefits to all causes of Allah SWT (tahbis s al-așl wa tasbill al-manfa 'ah). ${ }^{20}$ However, a waqf donor will still have the right to use the benefits from the waqf property if donated as waqf am, which would be further explained in the section on types of endowment and waqf funds.

\section{PHILOSOPHY OF GIVING}

Giving for charity or the benefits of others is a universal culture embraced by humanity that is encouraged by numerous religions. According to Ibrahim, the practice of giving by a person to those in need is a fundamental belief not only in Islam but Christianity as well. ${ }^{21}$ Singer asserts that the Jews are also

17 Al-Nawawīe Ab̄̄ Zakariyyā Maḥy al-Dīn Ibn Sharf, al-Majmū' Sharh alMuhadhdhab li al-Shirāzī, vol. 16 (Jeddah: Maktabah al-Irshād, 1980), 241; Ibn Qudāmah, Abī Muḥammad 'Abd Allāh Ibn Aḥmad Ibn Muḥammad al-Maqdisī, al-Mughn̄i, vol. 8 (Qāhirah: Hajr, 1992), 84; Ibn 'Ābidīn, Muḥammad Amīn, Radd al-Muhtār 'ala al-Durr al-Mukhtār Sharh Tanwīr al-Abṣār, vol. 6 (Bayrūt: Dār alMa'rifah, 2000), 516-517.

18 Al-Hammām, K. D., Sharḥ Fath al-Qadīr 'ala al-Hidāyah Sharh Bidāyah alMubtadi', vol. 6 (Bayrūt: Dār al-Kutub al-'Ilmiyyah, 2003), 191; al-Sharbīn̄, Shams al-Dīn Muḥammad Ibn Muḥammad al-Khāțib, Mughn̄̄ al-Muḥtāj ilā Ma 'rifâtē Ma 'ānī Alfāz al-Minhāj, vol. 2 (Bayrūt: Dār al-Ma'rifah, 1997), 485; alRahayban̄̄, M. S., Matāalib Uli al-Nuhā fì Sharh Ghayah al-Muntahā, vol. 6 (n.p.: n.p., 2000), 6 .

19 Al-Zuhaylī, Wahbah, al-Fiqh al-Islāmī wa Adillatuh, vol. 8 (Dimashq: Dār al-Fikr, 2010), 153.

20 Nazīh Hammād, Mu 'jam al-Muștalahāat al-Iqtiṣādiyyah fì Lughah al-Fuqahā' (Riyāḍ: Dār al-'Alamiyyah li al-Kitāb al-Islāmī, 1995), 353.

21 Barbara Lethem Ibrahim, 'Introduction: Arab Philanthropy in Transition,' in From Charity to Social Change, ed. B. L. Ibrahim \& D. H. Sherif (New York: The American University in Cairo Press, 2008), 2. 
encouraged to practise giving as a form of charity that represents a right for the poor or an impartial privilege by the community. ${ }^{22}$ The act of charity not only can alleviate the suffering faced by the poor but also can maintain the balance and order of a society. However, Singer believes that some motivations and expectations can exist from both donors and recipients in shaping the act of charitable giving. ${ }^{23}$

For waqf, the factors that have influenced Muslim donors to contribute properties are based on values towards humanity and generosity in helping those in need, as discussed by Zaki Halim Mubarok. ${ }^{24}$ However, the crucial factor of fulfilling the religious obligation to safeguarding wealth ( $m \bar{a} l$ ) under the maqāsid al-sharī'ah has become a catalyst for waqf. This purpose has been discussed extensively by various scholars such as Siti Khadijah, Muhammad Sabki and Ismail, ${ }^{25}$ Tawfique, ${ }^{26}$ as well as Nasrul Hisyam, Mohd Arafat, Muhibbuddin, Nurul Atikah, Mohd Muslim, \& Mohd Muammar. ${ }^{27}$ Muslims who contribute property into waqf shows that their obligation to the religion. However, this insight contradicts to the understanding of endowment. As argued by Fishman, ${ }^{28}$ Brown, Dimmock, Kang, and Weisbenner, ${ }^{29}$ as well as the American Council on Education, ${ }^{30}$ the purpose of endowment varies based on donors that are permitted by law. Since waqf is one of the methods

22 Amy Singer, Charity in Islamic Societies (Cambridge: Cambridge University Press, 2008), 4.

23 Singer, Charity in Islamic Societies, 4.

24 Zaki Halim Mubarok, 'Peranan Wakaf dalam Membangun Identitas Muslim Singapura,' Jurnal Al-Awqaf, vol. 7/1 (2014): 1.

25 A.M. Siti Khadijah, S. Muhammad Sabki, \& A. Ismail, 'Philanthropic Commitment Traits for Waqf in Higher Education,' Global Journal Al-Thaqafah, vol. 7/1 (2017): 76.

26 Tawfique al-Mubarak, 'The Maqasid of Zakah and Awqaf and Their Roles in Inclusive Finance,' Islam and Civilisational Renewal, vol. 7/2 (2016): 217.

27 Nasrul Hisyam Nor Muhamad, Mohd Arafat Jaafar, Muhibbuddin Abdullah, Nurul Atikah Nizaludin, Mohd Muslim Salleh, \& Mohd Muammar Mohd Zin, 'Konsep Maqasid Syariah dalam Pengurusan Wakaf,' International Journal of Islamic and Civilizational Studies, vol. 2/3 (2015): 4.

28 James J. Fishman, 'What Went Wrong: Prudent Management of Endowment Funds and Imprudent Endowment Investing Policies,' The Journal of College and University Law, vol. 40/2 (2014): 200.

29 Jeffrey R. Brown, Stephen G. Dimmock, Jun-Koo Kang, \& Scott J. Weisbenner, 'How University Endowments Respond to Financial Market Shocks: Evidence and Implications,' American Economic Review, vol. 104/3 (2014): 934.

30 American Council on Education, Understanding College and University Endowments (Washington, D.C.: American Council on Education, 2014), 3. 
to perform șadaqah jāriyah, various verses in the al-Quran can be quoted as support towards this practice, although the term waqf is not explicitly mentioned. For example:

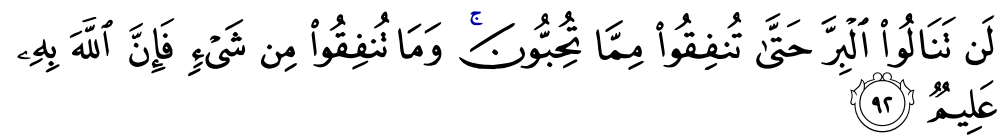

"Never will you attain the good [reward] until you spend [in the way of Allah] from that which you love. And whatever you spendindeed, Allah knows of it."

(Surah Āli-'Imrān, 3: 92)

Based on the verse above, Allah SWT describes the necessity to sacrifice valuable property through sadaqah jāriyah to attain the essence of perfect welfare and goodness. The act of sacrificing property is proof of a servant convinced by the reward promised by Allah SWT. In his tafsīr, Ibn Kathīr has stated that Sharik, Abī Isḥāq, and 'Amrū bin Maymun have narrated the meaning of al-birr as heaven, in which the servants of Allah SWT will not enter heaven until șadaqah or infāq are performed..$^{31}$ Besides referring to heaven, albirr is also defined as a reward from Allah SWT or good deeds ('amal șālih), which deserves to be awarded, based on tafsīr of al-Qurțūbī. ${ }^{32}$

According to Tabari, the word tunfiqu refers to giving everything one loves and avoiding himself or herself from holding on to the possessions. ${ }^{33}$ Furthermore, Anas bin Malik has reaffirmed that when the verse is initially revealed, a wealthy companion of Prophet Muhammad, Abu Talhah, has gone to the Prophet to perform waqf on the land that he loved the most in Bairaha', Madinah. This land has been located in front of the mosque that Rasulullah SAW has often visited. Abū Talhah has intended to reap goodness and reward from his waqf, ${ }^{34}$ which shows that the practice does not only encompass the obedience of a servant in the religion but is also about obtaining the ultimate

31 Ibn Kathīr, Abū Fidā' Ismā'il Ibn 'Umar, al-Qurshī al-Damashqī, Tafsīr al-Qur 'ān al- 'Ażīm, vol. 2 (Riyāộ: Dār Taybah li al-Nashr wa al-Tawzī', 2009), 73.

32 Al-Qurṭūbī, Abī Wālid Muḥammad Ibn Aḥmad Ibn Muḥammad Ibn Aḥmad Ibn Rushd, al-Jāmi ' li Aḥkām al-Qur'ān, vol. 5 (Bayrūt: Al-Risālah Publishers, 2006), 201.

33 Al-Ṭabarī, Abū Ja'far Muhammad Ibn Jarīr, Jamī' al-Bayān 'an Ta 'wīl al-Qur'ān, vol. 3 (n.p.: Maktabah Mușțafā al-Bābī al-Ḥalābī, 1968), 347.

34 Ibn Kathīr, Abū Fidā' Ismā'il Ibn 'Umar, al-Qurshī al-Damashqī, Tafsīr al-Qur 'ān al-'Azìm, vol. 2, 73. 
reward from Allah SWT. Additionally, in another verse in al-Quran, Allah SWT has reminded His servants that:

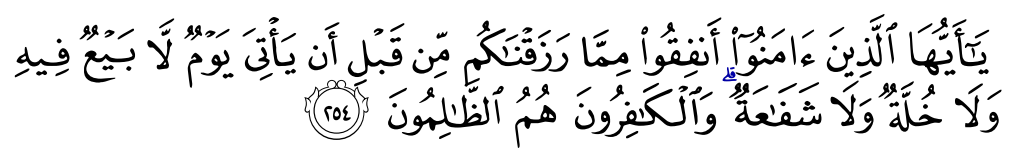

"O you who have believed, spend from that which We have provided for you before there comes a Day in which there is no exchange and no friendship and no intercession. And the disbelievers - they are the wrongdoers."

(Surah al-Baqarah, 2: 254)

The above verse elaborates the command by Allah SWT command to perform șadaqah from sustenance for charitable purposes. This act can provide believers with salvation in the hereafter, whereby no one can help except to those who have given within the path of charity for Allah SWT. ${ }^{35}$ There is also a șahinh hadīth that encourages waqf practice as reported by al-Nawawī; alTirmidhī; Abū Dāwud; and al-Nasā'̄̄ as follows:

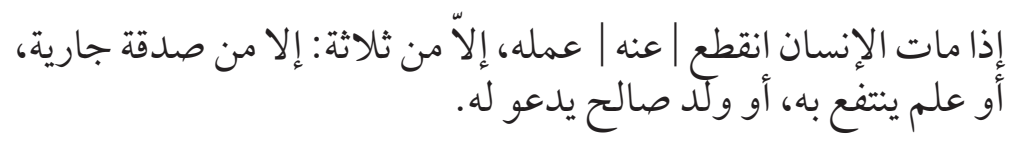

"When a man dies, all his good deeds come to an end except for three things: șadaqah jāriyah (ongoing charity), beneficial knowledge and a righteous son who prays for him." 36

Al-Nawawi has argued that this hadith describes the encouragement of waqf practice, and the great reward is known to be sahịh. ${ }^{37}$ Jumhür 'ulamā'

35 Ibn Kathīr, Abū Fidā' Ismā'il Ibn 'Umar, al-Qurshī al-Damashq̄̄, Tafsīr al-Qur'ān al-'Azìm, vol. 2, 675.

36 Al-Nawawī, Abī Zakariyyā Maḥy al-Dīn Ibn Sharf, Sharḥ Sahịh Muslim bi Sharh al-Imām Muhy al-Dīn al-Nawawī, vol. 11 (Bayrūt: Dār al-Ma'rifah, 2005), 87, "Kitāb al-Wașiyyah, Bāb Mā Yalhaq al-Insān min al-Thawāb ba'da Wafātih," hadīth no. 4199; al-Tirmidhī, Abū 'īsā Muhammad Ibn 'Īsā Ibn Sawrah Ibn Mūsā, al-Jāmi ' al-Sậ̄̄h wa Huwa Sunan al-Tirmidhī, vol. 3 (Bayrūt: Dār al-Kitāb al'Alamiyah, n.d.), 660, "Kitāb al-Aḥkām, Bāb fī al-Waqf," hadīth no. 1376; Abū Dāwud, Sunan Abū Dāwud, vol. 4 (Bayrūt: Dār al-Risālah al-'Alamiyah, 2009), 506, "Kitāb al-Wașāyā, Bāb fī al-Șadaqah 'an al-Mayyit," hadīth no. 2880; alNasā'̀̄, Sunan al-Nasā' '̄: Bi Sharh al-Hafìz Jalāl al-Dīn al-Suyūṭ̄, vol. 5 (Bayrūt: Dār al-Kitāb al-'Alamiyah, n.d.), 251, "Kitāb al-Wașāyā, Bāb Faḍl al-Ṣadaqah 'an al-Mayyit," hadīth no. 3651.

37 Al-Nawawī, Abī Zakariyyā Maḥy al-Dīn Ibn Sharf, Sharḥ Ṣaḥ̄ḥ Muslim bi Sharḥ al-Imām Muhy al-Dīn al-Nawawī, vol. 11, 88. 
have also interpreted the word șadaqah järiyah in this hadith as waqf because the reward of sadaqah järiyah continuously benefit the person who performs waqf, while the reward of other charities is not always be considered as sadaqah jāriyah or waqf..$^{38}$

In contrast, the reason that motivates the donors to contribute to an endowment fund is the value of love. As stated by Brodman ${ }^{39}$ and Singer, ${ }^{40}$ a person who is committed to charity possesses the value of love towards mankind. A study conducted by Bekkers has yielded giving to be strongly associated with the expression of love towards humanity. ${ }^{41}$ Thus, Rohayati, Najdi, and Williamson have argued that the act of giving for charity is not just to fulfil the needs of the poor, but to improve humanity as well. ${ }^{42}$ Grady supports this assertion by claiming that philanthropy can establish relationships among humans through the process of giving and receiving. ${ }^{43}$ However, Jews and Christians encourage the followers to give than to receive since Jesus has stated that:

\section{"It is more blessed to give than to receive." 44}

Besides humanity, another aspect that influences a person to contribute to philanthropic funds is generosity, which can be proven through findings from Lwin and Phau. The study argues that besides financial security, generosity is another factor that leads to charitable donations. ${ }^{45}$ A study by Grady also claims that philanthropy is an expression of human generosity, which exists in

38 Al-Sharbīnī, Shams al-Dīn Muḥammad Ibn Muhammad al-Khāṭib, Mughñ̄ alMuḥtāj ilā Ma 'rifātī Ma 'ān̄̄ Alfà̃z al-Minhāj, vol. 2, 485.

39 J.W. Brodman, Charity \& Religion in Medieval Europe (United States of America: The Catholic University of America Press, 2009), 10.

40 Singer, Charity in Islamic Societies, 4.

41 René Bekkers, 'Traditional and Health-Related Philanthropy: The Role of Resources and Personality,' Social Psychology Quarterly, vol. 69/4 (2006), 349.

42 Mohd Isa Rohayati, Youhanna Najdi, \& John C. Williamson, 'Philanthropic Fundraising of Higher Education Institutions: A Review of the Malaysian and Australian Perspectives,' Sustainability, vol. 8/541 (2016), 1.

43 Heather Grady, 'Philanthropy as an Emerging Contributor to Development Cooperation,' (Paper presented, Conference International Development Cooperation: Trends and Emerging Opportunities: Perspectives of the New Actors, Istanbul, June 2014), 4.

44 'Acts 20:35,' Bible Hub, accessed on 21 July 2020.

45 Michael Lwin \& Ian Phau, 'Characteristics of Charitable Donors in Australia,' in Recent Advances in Retailing and Services Science Conference, ed. H. Timmermans (Istanbul, Turkey: Recent Advances in Retailing and Services Science, 2010), 15. 
every culture and religion in this world. ${ }^{46}$ Furthermore, Bekkers has described that generosity exists in the intentions of people to help the underprivileged due to emphatic concern, helpfulness, and social value orientations. ${ }^{47}$ Lee and Chang have also found that generosity to give is due to having a high emphatic disposition and a keen awareness of charitable organisations. ${ }^{48}$ From the aspect of charitable giving within the education sector, especially in higher education, Cascione asserts that:

"Giving to higher education institutions is best understood as philanthropic since it is most often indirect and programmatic, and the institution is expected to deliver the means for the instruction of other benefits of education." 49

\section{TYPES OF ENDOWMENT AND WAQF FUNDS IN HIGHER EDUCATION}

There are three types of endowment funds, whereby the first type of endowment is a true endowment. According to Sherlock, Gravelle, Crandall-Hollick, and Stupak, as well as Brown, Dimmock, Kang, and Weisbenner, a true endowment is funds specified by the donor to be held in perpetuity. ${ }^{50}$ This type of endowment is commonly restricted for the use of principal and/or income, as described

46 Grady, 'Philanthropy as an Emerging Contributor to Development Cooperation,' 8.

47 Bekkers, 'Traditional and Health-Related Philanthropy: The Role of Resources and Personality,' 349.

48 Yu-Kang Lee \& Chun-Tuan Chang, 'Who Gives What to Charity? Characteristics Affecting Donation Behavior,' Social Behavior and Personality, vol. 35 / 9 (2007), 1177.

49 G. L. Cascione, Philanthropists in Higher Education: Institutional, Biographical, and Religious Motivations for Giving (New York: Routledge Falmer, 2003), 5.

50 Molly F. Sherlock, Jane G. Gravelle, Margot L. Crandall-Hollick, \& Jeffrey M. Stupak, 'College and University Endowments: Overview and Tax Policy Options,' Congressional Research Service, 2015, 2; but may also consist of cash or property. Current tax law benefits endowments and the accumulation of endowment assets. Specifically, endowment fund earnings are exempt from federal income tax. Additionally, taxpayers making contributions to college and university endowment funds may be able to deduct the value of their contribution from income subject to tax. The purpose of this report is to provide background information on college and university endowments, and discuss various options for changing their tax treatment. This report uses data from the U.S. Department of Education, the National Association of College and University Business Officers (NACUBO). Brown, Dimmock, Kang, \& Weisbenner, 'How University Endowments Respond to Financial Market Shocks: Evidence and Implications,' 934. 
by the National Association of College and University Business Officers (NACUBO) ${ }^{51}$ The Financial Accounting Standards Board (FASB) claims that a true endowment is often referred to as a permanently restricted endowment that must be maintained permanently; not used up, expended, or otherwise exhausted. ${ }^{52}$ Hence, a true endowment is often channelled as scholarship funds, as well as financial support to universities. The second type of endowment fund is a term endowment, which refers to the funds restricted by the donor for a specified period. According to NACUBO and Sherlock et al., after the set of time has passed, unused funds or principal may become unrestricted. ${ }^{53}$ This description implies that funds may be expended after the expiration of a stated period depending on the donors. Therefore, the endowment can also be classified as a temporarily restricted endowment. The third type of endowment is a quasi-endowment or sometimes called funds functioning. Sherlock et al. define this type of endowment as unrestricted funds being treated as an endowment to be spent if selected. ${ }^{54}$ On the other hand, NACUBO claims that this unrestricted fund can be spent for any relevant purposes depending on the

51 National Association of College and University Business Officers, Commonfund Study of Endowments (Washington, D.C.: NACUBO, 2017), 120.

52 'Statement of Financial Accounting Standards No. 117, Financial Statements of Not-for-Profit Organizations,' 48.

53 National Association of College and University Business Officers, Commonfund Study of Endowments, 126; Sherlock et al., 'College and University Endowments: Overview and Tax Policy Options,but may also consist of cash or property. Current tax law benefits endowments and the accumulation of endowment assets. Specifically, endowment fund earnings are exempt from federal income tax. Additionally, taxpayers making contributions to college and university endowment funds may be able to deduct the value of their contribution from income subject to tax. The purpose of this report is to provide background information on college and university endowments, and discuss various options for changing their tax treatment. This report uses data from the U.S. Department of Education, the National Association of College and University Business Officers (NACUBO), 2.

54 Sherlock et al., 'College and University Endowments: Overview and Tax Policy Options, but may also consist of cash or property. Current tax law benefits endowments and the accumulation of endowment assets. Specifically, endowment fund earnings are exempt from federal income tax. Additionally, taxpayers making contributions to college and university endowment funds may be able to deduct the value of their contribution from income subject to tax. The purpose of this report is to provide background information on college and university endowments, and discuss various options for changing their tax treatment. This report uses data from the U.S. Department of Education, the National Association of College and University Business Officers (NACUBO), 2. 
votes by the Board of Trustees. ${ }^{55}$ Getz also argues that this type of fund can only be used when instructed by the donors. ${ }^{56}$

Meanwhile, there are two types of funds under waqf. The first type of waqf is known as waqf khās, whereby the waqf donor or wāqif has specified the purposes and beneficiaries of the funds. According to Asmak, the wāqif will determine the recipients of waqf, as well as the specific purposes from the initial act of giving. ${ }^{57}$ One of the examples of waqf khas in HEIs is the land donated as waqf to build relevant facilities such as hostels, cafeteria, and students' activities centre. The second type of waqf is waqf ' $\bar{a} m$, which refers to the waqf practice that is dedicated for general charitable purposes without specification of any specific beneficiaries (individuals or any organisations/institutions) or particular purposes. Waqf 'àm can be utilised for general charitable purposes that strengthen the position, as well as the image of Islam and ummah. For instance, a person can use his land for waqf to Muslims in general or for any charitable purposes. According to Asmak, specific conditions for waqf are not imposed by the waqf donor under waqf ' $\bar{a} m .^{58}$

\section{ELEMENTS OF ENDOWMENT AND WAQF FUNDS IN HIGHER EDUCATION}

Two elements that distinguish endowment and waqf funds that are discussed based on the earlier definitions are perpetuity and rights of ownership. Although both types of funds have the element of perpetuity, the reason for the element is different. For endowment, the element of perpetuity can be observed through the principle of the given contribution must be invested to generate income and fund operating expenses and activities of an institution. This understanding has been extensively discussed by various scholars such as Pérez-Esparrells and Torre, Gilbert and Hrdlicka, Madanchi, Shahverdiani,

\footnotetext{
55 National Association of College and University Business Officers, Commonfund Study of Endowments, 124.

56 Malcolm Getz, 'Endowment,' The Bottom Line, vol. 4/2 (2007): 37.

57 Asmak Ab Rahman, 'Peranan Wakaf dalam Pembangunan Ekonomi Umat Islam dan Aplikasinya di Malaysia,' Jurnal Syariah, vol. 17/ 1 (2009): 118.

58 Asmak, 'Peranan Wakaf dalam Pembangunan Ekonomi Umat Islam dan Aplikasinya di Malaysia,' 118.
} 
and Hamidifar, as well as Dyachkova. ${ }^{59}$ In Islam, the element of perpetuity is known as al-ta'bid, which is observed through the need to preserve the contributed property. The need to preserve can be referred to as cannot be transferred for other purposes following the advice by the Prophet, as narrated by fiqh cholars that waqf property should not be sold, given as a present, and inherited. ${ }^{60}$ Since the contributed property must be preserved, waqf is often associated with the contribution in the form of fixed assets, such as lands and houses, with an assumption that these assets are permanent and durable. Nonpermanent properties or those with a short life span such as food and drinks cannot be used as waqf. Thus, the element of the perpetuity for waqf can be observed, which Nizam describes as being parallel with the definitions made by a majority of scholars. ${ }^{61}$

Besides, the endowment has flexible ownership in terms of rights of ownership. Donors who have donated funds as a true endowment or a term endowment are regarded as gifts or bequests. This concept is consistent with FASB, which has mentioned that "endowment funds generally are established by donor-restricted gifts and bequests to provide a permanent endowment or

59 Pérez-Esparrells and Torre, 'The Challenge of Fundraising in Universities in Europe, $|\backslash r| \backslash$ nbut also new means of raising supplementary philanthropic (private' 56; Thomas Gilbert \& Christopher Hrdlicka, 'Why Are University Endowments Large and Risky?,' The Review of Financial Studies (2015): 3; Mehdi Madanchi, Shadi Shahverdiani, \& Fatemah Hamidifar, 'Endowment and Charity Financing Model to Develop Science and Technology,' International Journal of Finance and Managerial Accounting, vol. 1/4 (2016): 56; E. Dyachkova, 'Managing Endowment Fund Income in Universities,' Educational Studies, vol. 1 (2016), 225.

60 Al-Bukhārī, Abī 'Abd Allāh Muhammad Ibn Ismā'il al-Ju'fì, Saḥ̄h al-Bukhārī (Riyāụ: Dār al-Salām, 1999), 451, "Kitāb al-Shurūṭ, Bāb al-Shurūt fī al-Waqf," hadīth no. 2737; al-Tirmidhī, Abū 'Īsā Muhammad Ibn 'Īsā Ibn Sawrah Ibn Mūsā, al-Jāmi " al-Ṣaḥị̣ wa Huwa Sunan al-Tirmidhī, 659, "Kitāb al-Aḥkām, Bāb fī alWaqf," hadìth no. 1375; al-Nasā'̀̄, Sunan al-Nasā̄'̄: Bi Sharh al-Hafìz Jalāl alDīn al-Ṣyūṭ̄i, vol. 5, 232, "Kitāb al-Aḥbās, Bāb Habs al-Mashā', hadīth no. 3604; al-Nawawī, Abī Zakariyyā Maḥy al-Dīn Ibn Sharf, Sharh Sahīh Muslim bi Sharh al-Imām Muhy al-Dīn al-Nawawī, vol. 11 (Bayrūt: Dār al-Ma'rifah, 2005), 88, "Kitāb al-Wașiyyah, Bāb al-Waqf," hadīth no. 4200; Ibn Mājah, Abū 'Abd Allāh Muhammad Ibn Yazid al-Qazwin̄̄, Sunan Ibn Mājah, vol. 2 (Bayrūt: Dār Ihyyā' alKutub al-'Arabiyah, 1975), 801, "Kitāb al-Ṣadaqāt, Bāb min al-Waqf," hadīth no. 2396.

61 Niz̄ām, al-Fatawā al-Hindiyah, vol. 2 (Bayrūt: Dār al-Kutub al-'Ilmiyyah, 2000), 361. 
term endowment". ${ }^{62}$ According to Kazemi and Wilkens, these types of funds are owned by the institution. ${ }^{63}$ Nevertheless, in a different circumstance, the institution can transfer the ownership of the finds to possessions even if the funds were not initially donated as gifts. For quasi-endowment, which is also known as unrestricted funds, the funds do not belong to the institution. According to Getz; Sherlock et al., as well as Monti, if there is surplus money for the long term, the institution treats the funds as a gift, and would serve as a true endowment. ${ }^{64}$ Therefore, the quasi-endowment is also known as funds functioning as endowments.

Besides, waqf has an element of al-mu 'tamad or irrevocable, which means that the process for waqf is enforced once the donor declares the property as waqf. According to Abu Yusuf, the process of waqf is used and valid once the donor makes the declaration. From that point on, the property no longer belongs to the donor but has been transferred as possession of Allah SWT. Hence, the waqf is considered to be beneficiaries or mawqüf 'alayh, which cannot be revoked, as described by al-Sarakhsī. ${ }^{65}$ Al-Kasānī asserts that this opinion is also accepted by a majority of scholars from the four Islamic schools of thought. ${ }^{66}$ In the context of education, higher institutions have no rights on

62 'Statement of Financial Accounting Standards No. 117, Financial Statements of Not-for-Profit Organizations,' 48.

63 Hossein Kazemi \& Kathryn Wilkens, 'A Simple Approach to the Management of Endowments,' All About Alpha, 2017, see http://www.allaboutalpha.com/ blog/2017/08/07/a-simple-approach-to-the-management-of-endowments/, accessed on 19 October 2018.

64 Getz, 'Endowment,' 37; Sherlock et al., 'College and University Endowments: Overview and Tax Policy Options,but may also consist of cash or property. Current tax law benefits endowments and the accumulation of endowment assets. Specifically, endowment fund earnings are exempt from federal income tax. Additionally, taxpayers making contributions to college and university endowment funds may be able to deduct the value of their contribution from income subject to tax. The purpose of this report is to provide background information on college and university endowments, and discuss various options for changing their tax treatment. This report uses data from the U.S. Department of Education, the National Association of College and University Business Officers (NACUBO), 2; Frank Monti, 'The Surprisingly Complex ABCs of Endowment Funds,' website of Inside Philanthropy, see https://www.insidephilanthropy.com/ the-gift-adviser/2015/3/4/the-surprisingly-complex-abcs-of-endowment-funds. html, accessed 24 February 2020.

65 Al-Sarakhs̄î, Abū Bakr Muhammad Shams al-Dīn, al-Mabsūṭ, vol. 12 (Bayrūt: Dār al-Ma'rifah, 1989), 41.

66 Al-Kasān̄̄, Abū Bakr Ibn Mas'ūd al-Ḥanāfî, Baḍ̄' 'i al-Sana'i` fì Tartīb alSharā'i`, vol. 8 (Bayrūt: Dār al-Kutub al-'Ilmiyyah, 2003), 383. 
the donated fund since the waqf belongs to Allah SWT. These institutions can only act as waqf managers (mutawallì) on the donations.

\section{GOVERNANCE OF ENDOWMENT AND WAQF FUNDS IN MALAYSIAN HIGHER EDUCATION}

McElhaney; Dimmock; Madanchi, Shahverdiani, and Hamidifar, as well as Kaffe, describe two types of legal structures that are internationally involved in managing endowment funds at HEIs. Firstly, as a part of the university itself; and secondly, as a separate legal entity, such as a foundation or investment management company. ${ }^{67}$ However, within the context of Malaysia, particularly in public universities, endowment funds are usually managed by the university, specifically, the financial division, which also acts as the bursary of the university. As already discussed by Baharom, Wiaam, and Sarafuddin who mentioned that endowment funds in the public universities in Malaysia are managed by bursaries, whereby a small investment or endowment unit is set up. ${ }^{68}$ Although the bursary office has the authority to receive and manage the endowment fund, the office is also responsible for reporting all endowment activities and financial status to the Board of Directors (BoD) of the individual university. ${ }^{69}$ Usually, the BoD consists of representatives from the government and three education officers who have been appointed by the Ministry of Education (MoE).

Since endowment is regarded as a trust fund, the legislation that governs this fund in Malaysia, which also involves higher education institutions, is

67 Robert Louie Stanton McElhaney, 'The Effects of Higher Education Endowment Management Practices on Endowment Performance' (Ph.D. Thesis, The University of Southern Mississippi, 2010), 38-39; Stephen G. Dimmock, 'Background Risk, and University Endowment Funds,' The Review of Economics and Statistics, vol. 94/3 (2012), 790; Madanchi, Shahverdiani, and Hamidifar, 'Endowment and Charity Financing Model to Develop Science and Technology,' 65; Charikleia Kaffe, 'Peer Effects in Investment Manager Selection: Evidence from University Endowments,' 2.

68 Baharom Abdul Hamid, Wiaam Hassan @ Kamarudin, \& Sarafuddin Abdul Syahid Sowell, 'The Endowment Fund as a Source of Sustainability for Higher Education in Malaysia: Maximising Investment Returns,' (ISRA Research Paper, Kuala Lumpur, 2018), 21.

69 Baharom, Wiaam, \& Sarafuddin, 'The Endowment Fund as a Source of Sustainability for Higher Education in Malaysia: Maximising Investment Returns,' 21. 
the Trustee Act 1949 (Act 208). This act consists of 69 provisions that focus on matters concerning trust, executorship and administratorship, which are stipulated in Section 2 of this act. ${ }^{70}$ Although the Trustee Act 1949 (Act 208) functions as the primary source of trust law, Dhillon, Mohammed, and Miin argue that the judiciary in Malaysia will still refer to the English law in deciding cases. For example, in the case of Liew Choy Hung v. Fork Kian Seng, the judge has referred to the case of Springgette v. Defoe, Pettit v. Pettit and Halsbury's Laws of England. ${ }^{71}$ This practice has been specified in the Civil Law Act 1956 (Section 3), which states that the judiciary in Malaysia is allowed to use the Common Law of the United Kingdom (U.K.) in situations when appropriate, provided that the case is confined to the cut-off date. ${ }^{72}$

On the other hand, the implementation of endowment by a university does not give rise to any legal problems as there are specific regulations that allow the university to receive and manage the investments for endowment funds. These regulations are predetermined in the Universities and University Colleges Act 1971, specifically Item 4 (1) of the First Schedule. ${ }^{73}$ Based on this stipulation, the university acts as a trustee of the properties that have been endowed. However, the implementation for waqf by the university is quite complicated as waqf in Malaysia is under state jurisdiction (except for Wilayah Persekutuan Kuala Lumpur, Labuan, and Putrajaya) as stipulated in List 2 of the Ninth Schedule within the Federal Constitution. ${ }^{74}$ For example, in several state enactments, Majlis Agama Islam Negeri (MAIN) is stated to be the sole trustee for all waqf assets located within a state. ${ }^{75}$ Hence, if a university wants to implement the waqf fund within the institution, the university would first need to seek permission from the respective MAIN of the state. If the permission is granted, the university holds the status of mutawalli or waqf manager and is, therefore, entitled to accept and manage the waqf fund. Based on this context,

\footnotetext{
$70 \quad$ Trustee Act 1949 (Act 208), 7.

71 Guru Dhillon, Noor Mohammed, \& Ng Yih Miin, 'Equity \& Trust's Law Applications in Malaysia, UK and US - In Tandem or Apart?' Current Law Journal, vol. 1/Ixxiv (2011): 6.

72 Civil Law Act 1956 (Act 67), 7-9.

73 Universities and University Colleges Act 1971 (Act 30), 36.

74 Federal Constitution, 223.

75 See Section 4 of the Wakaf (State of Selangor) Enactment 2015; Section 32 of the Wakaf (State of Malacca) Enactment 2005; Section 5 of the Wakaf (State of Negeri Sembilan) Enactment 2005.
} 
Siti Mashitoh, Asmak, and Azizi establish mutawalli as the second level within the hierarchy of waqf management in Malaysia. ${ }^{76}$

As presented in the Purple Book, the Ministry of Education, Malaysia has suggested three possible governance models for waqf that can be adopted by public universities in Malaysia. ${ }^{77}$ The illustration and explanation of each model can be found below.

Figure 1: Model 1 of Waqf Governance at Public Universities

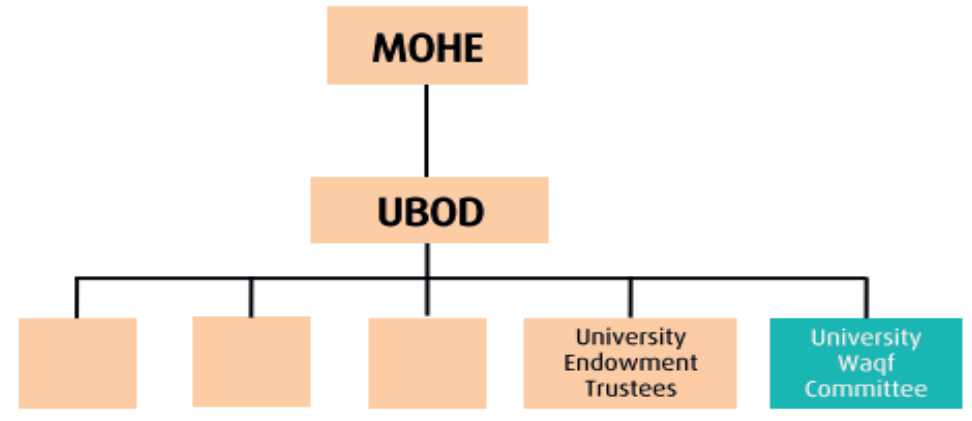

Source: MoE, Putrajaya, $2016 .^{78}$

The first model, as shown above, recommends the university to set up a unit or department under the management of the university. The waqf committee is placed under the $\mathrm{BoD}$ of the university and acknowledged to be one of the Board committees. This recognition allows the management of the university to have authority in all decisions, accounts and financial management related to the waqf activities. This model is similar to the model applied for the endowment at most public universities, as discussed earlier.

76 Siti Mashitoh Mahamood, Asmak Ab. Rahman, \& Azizi Che Seman, 'Cabaran Pelaksanaan Wakaf Universiti Awam Di Malaysia: Analisis Menurut Perundangan Di Malaysia,' Kanun, vol. 30/2 (2018): 396.

77 The University Transformation Programme (UniTP) Purple Book: Enhancing University Income Generation, Endowment \& Waqf, 25-26.

78 The University Transformation Programme (UniTP) Purple Book: Enhanching University Income Generation, Endowment \& Waqf, 25. 
Figure 2: Model 2 of Waqf Governance at the Public Universities
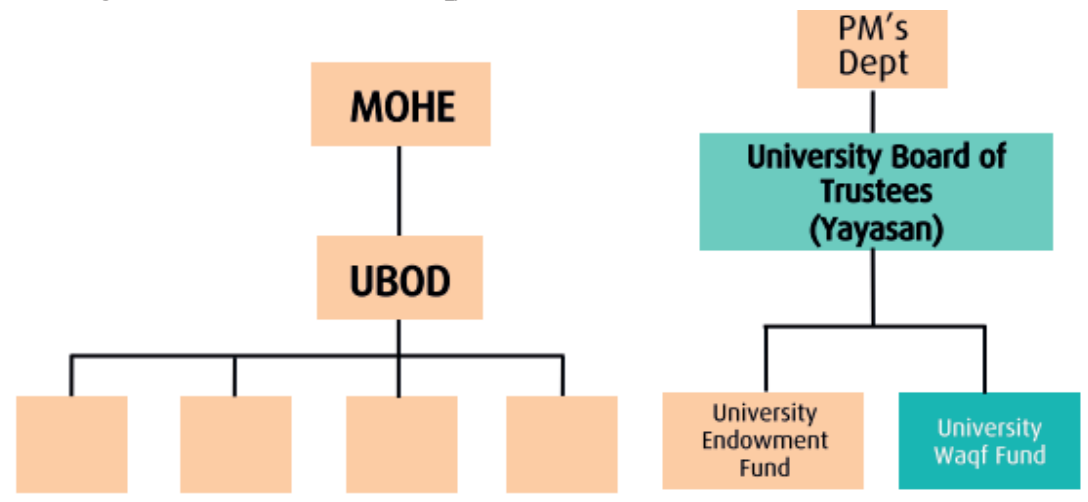

Source: MoE, Putrajaya, 2016. ${ }^{79}$

The second model, as shown above, recommends the university to set up an office for waqf under the Board of Trustees (BoT). The university waqf fund is placed under BoT as a project under the University Foundation (Yayasan), which has a separate account and financial management. Meanwhile, the third model, as shown below, recommends the university to establish a University Waqf Board (UWB) as a separate and independent entity. The collaboration, coordination, roles and responsibilities of the UWB are described in a written agreement or waqf deeds. The members of the UWB would consist of representatives from the MAIN and the university.

79 The University Transformation Programme (UniTP) Purple Book: Enhanching University Income Generation, Endowment \& Waqf, 25. 
Figure 3: Model 3 of Waqf Governance at the Public Universities

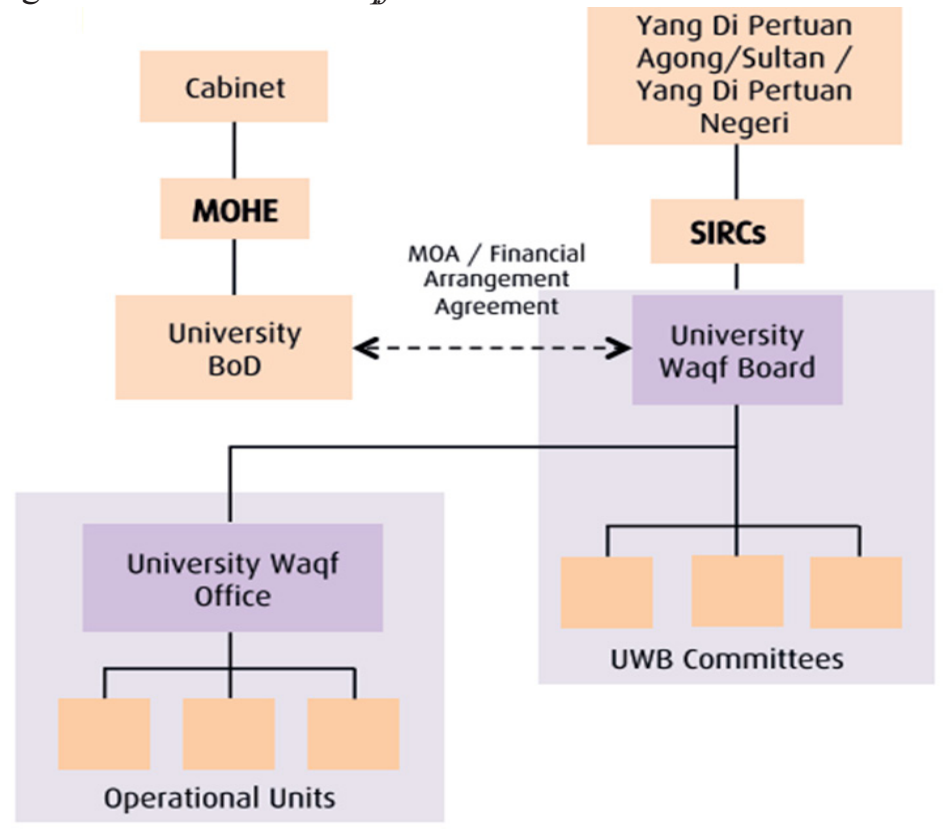

Source: MoE, Putrajaya, $2016 .^{80}$

The income derived from waqf property in every state in Malaysia is necessary to be distributed to the MAIN (after deducting the purposes and reinvestment of waqf for income generation) as the sole trustees. This procedure occurs when the university needs to obtain permission from the MAIN in implementing waqf funds from waqf properties that can generate income. Nonetheless, this practice refers to waqf from the income and not the principal. The model for income distribution of waqf has been proposed by Siti Mashitoh, Asmak, and Azizi, whereby $60 \%$ of the income is suggested to be used for waqf purposes. The remaining $20 \%$ should be used for reinvestment, while $15 \%$ is specified for waqf management in the university. Only $5 \%$ of the income is reserved for the MAIN. ${ }^{81}$ By having MAIN as one of the beneficiaries of the waqf income, the university can play a role in sustaining the waqf fund. The proposed model is illustrated in the figure below.

$80 \quad$ The University Transformation Programme (UniTP) Purple Book: Enhanching University Income Generation, Endowment \& Waqf, 26.

81 Siti Mashitoh Mahamood, Asmak Ab Rahman, \& Azizi Che Seman, 'Pembentukan Institusi Pengajian Tinggi Berteraskan Wakaf di Malaysia: Cadangan Model Pelaksanaannya,' Jurnal Syariah, vol. 26/1 (2018): 13. 
Figure 4: Waqf's Income Distribution Model
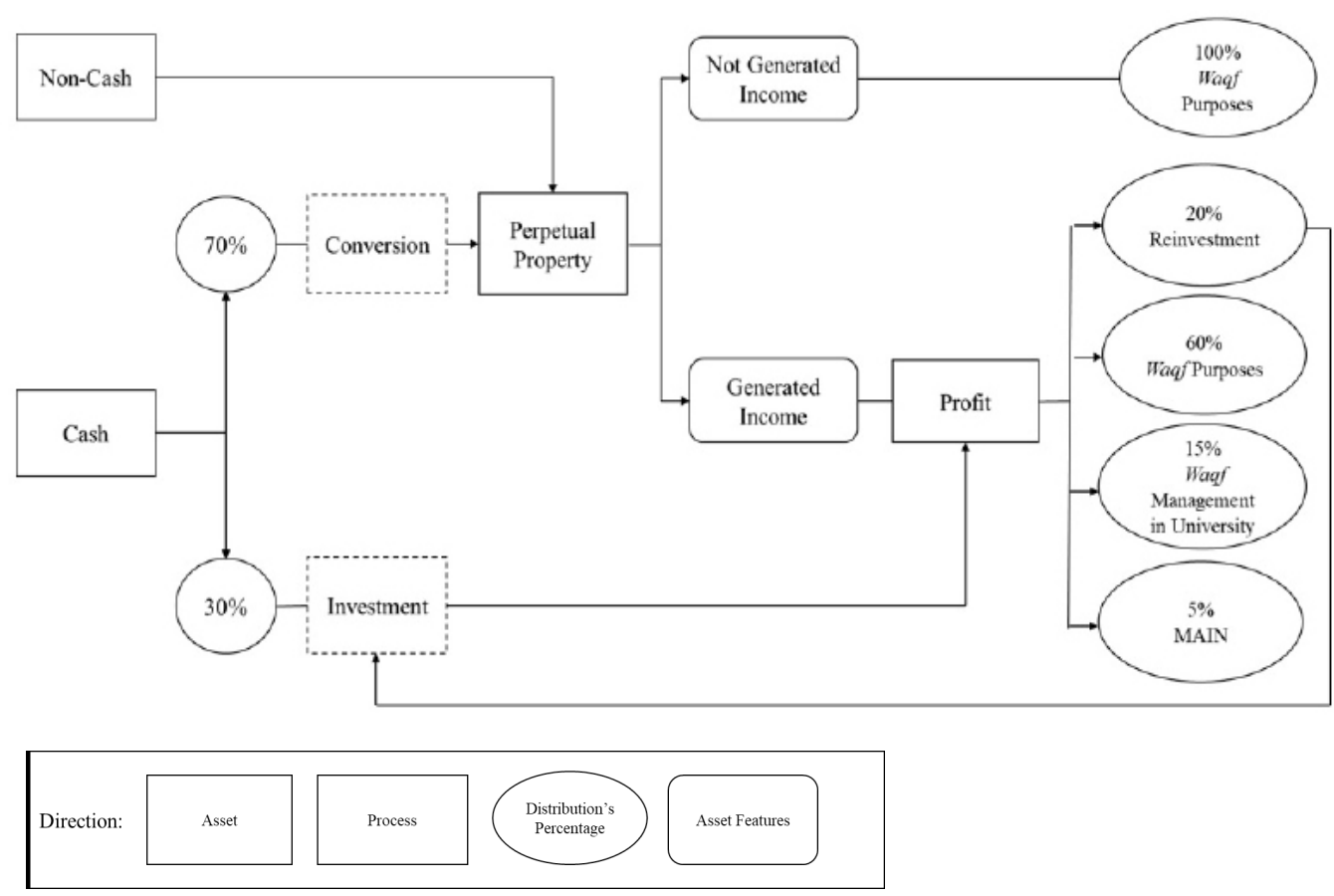

Source: Siti Mashitoh Mahamood, Asmak Ab Rahman, and Azizi Che Seman, $2018 .{ }^{82}$

\section{DISCUSSION}

The discussions above argue that once endowment donors contribute the property to the endowment fund of an institution, the institution would bear the responsibility to expand the funds through investment. The income generated from investment can be used to fund the operating costs of the institution. In contrast, once the waqf donors contribute the properties to the waqf fund, the waqf trustees or mutawalli must safeguard the property to ensure the benefits can be enjoyed by the beneficiaries as long as the property exists.

In terms of the philosophy of giving, the endowment donors contribute the property to endowment funds based on the factors of humanity and generosity.

82 Siti Mashitoh, Asmak, \& Azizi, 'Pembentukan Institusi Pengajian Tinggi Berteraskan Wakaf Di Malaysia: Cadangan Model Pelaksanaannya,' 13. 
On the other hand, apart from these two factors, there is another factor that distinguishes waqf from the endowment, which is to fulfil the religious obligation to safeguard the wealth. Furthermore, endowment and waqf funds are based on two types of outcomes, namely specific and unspecific. For endowment, the specific types of funds are known as true endowment and term endowment, while the unspecific type of fund is known as quasiendowment. For waqf, the specific type of fund is known as waqf khas, while the unspecific type of fund is called as waqf am. Both funds have the element of perpetuity which can be observed through investments that generate income (for endowment) and preservation of contributed property (for waqf). This factor highlights the importance of these funds to be maintained in perpetuity. In terms of rights of ownership, endowment offers flexible ownership, while waqf belongs to Allah SWT.

In Malaysia, endowment funds of HEIs can be established under the BoD, within the financial division of the university. There are several laws governing endowment funds in this country, especially in higher education institutions, which are the Universities and University Colleges Act 1971, Local Legislation (Trust Act 1949), and English Law by referring to cases. The establishment of waqf in the university is quite complicated as the university will need to first obtain permission from the MAIN of the state as the sole trustee of the waqf property, as imposed by the federal constitution and state legislation. Under granted permission, the university holds the status of mutawalli, which qualifies the institution to accept and manage the waqf property. Three models can be used by a university to implement the waqf fund, as previously discussed. Due to the status of MAIN in the waqf property, any income generated needs to have a portion distributed to the MAIN. Hence, the factors that differentiate endowment and waqf funds are summarised in the table below.

Table 1: Differences between Endowment and Waqf Funds

\begin{tabular}{|c|c|c|c|}
\hline \multicolumn{2}{|c|}{ Aspect } & Endowment & Waqf \\
\hline \multicolumn{2}{|c|}{ Philosophy of giving } & Humanity and generosity & $\begin{array}{l}\text { To fulfil the reli- } \\
\text { gious obligation to } \\
\text { safeguarding wealth } \\
\text { ( } m a l \text { ) instead of hu- } \\
\text { manity and generos- } \\
\text { ity. }\end{array}$ \\
\hline \multirow[t]{2}{*}{ Element } & Perpetuity & Need to be invested & Need to be preserved \\
\hline & $\begin{array}{l}\text { Rights of } \\
\text { Ownership }\end{array}$ & Flexible & Allah SWT \\
\hline
\end{tabular}




\begin{tabular}{|c|c|c|c|}
\hline \multicolumn{2}{|c|}{ Aspect } & \multirow[b]{2}{*}{$\begin{array}{l}\quad \text { Endowment } \\
\\
\text { 1. Universities and } \\
\text { University Colleges Act } \\
\text { 1971 } \\
\text { 2. Local Legislation } \\
\text { (Trustee Act 1949) } \\
\text { 3. English Law (referring } \\
\text { to the case) - Civil Law Act } \\
\text { 1956 }\end{array}$} & \multirow{2}{*}{$\begin{array}{l}\qquad \boldsymbol{W a q f} \\
\\
\text { 1. Federal } \\
\text { Constitution } \\
\text { 2. State Legislation }\end{array}$} \\
\hline Governance & Law & & \\
\hline & Structure & $\begin{array}{l}\text { University's financial divi- } \\
\text { sion (bursary) }\end{array}$ & $\begin{array}{l}\text { 1. Model } 1 \\
\text { 2. Model } 2 \\
\text { 3. Model } 3\end{array}$ \\
\hline & Trustee & University & MAIN \\
\hline & $\begin{array}{l}\text { Need per- } \\
\text { mission }\end{array}$ & No & Yes (from MAIN) \\
\hline & $\begin{array}{l}\text { Income } \\
\text { sharing }\end{array}$ & No & Yes (with MAIN) \\
\hline
\end{tabular}

Source: Developed by Author for the Current Study.

Undoubtedly, the endowment is a trust fund that gives freedom to the university in accepting and managing (including investing) property that has been endowed. Since the university is not bound to any other organisation, the university has full power over the endowed property, including the income generated. For waqf, there are Islamic elements associated with the act of benevolence, such as a person who donates the property intends to fulfil maqāsid al-shari'ah and for the sake of Allah SWT. As the principle of waqf is preserved, waqf donors are assured that the property for waqf will remain forever. Moreover, waqf donors would be confident to donate to the universities because of the requirement in obtaining permission from the MAIN of the state for investment purposes. This process reaffirms the importance of an organisation that monitors the implementation of waqf funds in institutions (i.e., MAIN, which is also known as nazir). For universities with specific needs, such as having the freedom and full authority in managing the fund, an endowment is the best option. Meanwhile, universities that prefer funds adhering to the principles of Islam (especially to attract and convince Muslim donors) and abiding by the rules of an organisation that monitors the management, waqf would be the best option. 


\section{CONCLUSION}

The implementation of endowment and waqf funds is essential for an educational institution as a continuous source of finance. Although the implementation of both funds has a similar purpose, there are several factors within the concept of implementation that distinguishes these funds. In this study, the factors are found to be related to the philosophy of giving, elements of perpetuity and rights of ownership, as well as governance (law, structure, trustee, permission, and income sharing). The discussions on these differences can assist the universities, particularly in decision-making processes for institutions that have yet to implement any of these types of funds.

\section{REFERENCES}

'Acts 20:35,' Bible Hub, https://biblehub.com/acts/20-35.htm, accessed on 21 July 2020.

'Statement of Financial Accounting Standards No. 117, Financial Statements of Not-for-Profit Organizations,' 2010, http://www.fasb.org/cs/BlobSe rver?blobcol $=$ urldata $\&$ blobtable $=$ MungoBlobs \&blobkey $=\mathrm{id} \&$ blobwh ere $=1175823287301 \&$ blobheader $=$ application $\% 2$ Fpdf, accessed on 21 July 2020.

'Voluntary Support of Education' (London, Mexico City, Singapore \& Washington, D.C., 2020).

A. Amran \& J. Muhammad, 'Changes and Challenges in Financial Autonom,' in Governance Reforms in Public Universities of Malaysia, ed. F. Md. Taib \& M. N. L. Y. Abdullah (Pulau Pinang: Penerbit Universiti Sains Malaysia, 2015), 59-77.

A. M. Siti Khadijah, S. Muhammad Sabki, \& A. Ismail, 'Philanthropic Commitment Traits for Waqf in Higher Education,' Global Journal AlThaqafah, vol. 7/1 (2017): 71-77.

Abū Dāwud, Sunan Abū Dāwud, vol. 4 (Bayrūt: Dār al-Risālah al-‘Alamiyah, 2009).

American Council on Education, Understanding College and University Endowments (Washington, D.C.: American Council on Education, 2014).

Amy Singer, Charity in Islamic Societies (Cambridge: Cambridge University Press, 2008). 
Asmak Ab Rahman, 'Peranan Wakaf dalam Pembangunan Ekonomi Umat Islam dan Aplikasinya di Malaysia,' Jurnal Syariah, vol. 17/1 (2009): 113-152.

Baharom Abdul Hamid, Wiaam Hassan@ Kamarudin, \& Sarafuddin Abdul Syahid Sowell, 'The Endowment Fund as a Source of Sustainability for Higher Education in Malaysia: Maximising Investment Returns,' ISRA Research Paper (2018).

Barbara Lethem Ibrahim, 'Introduction: Arab Philanthropy in Transition,' in From Charity to Social Change, ed. Barbara Lethem Ibrahim \& Dina H. Sherif (New York: The American University in Cairo Press, 2008), 1-21.

Al-Bukhārī, Abī 'Abd Allāh Muḥammad Ibn Ismā'il al-Ju'fī, Șaḥịh al-Bukhārī (Riyāụ: Dār al-Salām, 1999).

Carmen Pérez-Esparrells \& Eva M. Torre, 'The Challenge of Fundraising in Universities in Europe,' International Journal of Higher Education, vol. 1/2 (2012): 55-66.

Charikleia Kaffe, 'Peer Effects in Investment Manager Selection: Evidence from University Endowments,' 2019.

D. Bruce Johnstone, Financing Higher Education: Cost-Sharing in International Perspective (The Netherlands: Sense Publishers, 2006).

Dictionary of Contemporary English, 4th ed. (England: Pearson Education Limited, 2003).

E. Dyachkova, 'Managing Endowment Fund Income in Universities,' Educational Studies, vol. 1 (2016): 225-244.

Frank Monti, 'The Surprisingly Complex ABCs of Endowment Funds,' Inside Philanthropy, 2015, https://www.insidephilanthropy.com/the-giftadviser/2015/3/4/the-surprisingly-complex-abcs-of-endowment-funds. html, accessed on 24 February 2020.

G. L. Cascione, Philanthropists in Higher Education: Institutional, Biographical, and Religious Motivations for Giving (New York: Routledge Falmer, 2003).

Guru Dhillon, Noor Mohammed, \& Ng Yih Miin, 'Equity \& Trust's Law Applications in Malaysia, UK and US - In Tandem or Apart?' Current Law Journal, vol. 1/lxxiv (2011).

Al-Hammām, K. D., Sharh Fath al-Qadīr 'ala al-Hidāyah Sharḥ Bidāyah alMubtadi', vol. 6 (Bayrūt: Dār al-Kutub al-'Ilmiyyah, 2003). 
Heather Grady, 'Philanthropy as an Emerging Contributor to Development Cooperation,' (Paper presented, Conference International Development Cooperation: Trends and Emerging Opportunities: Perspectives of the New Actors, Istanbul, June 2014).

Hossein Kazemi \& Kathryn Wilkens, 'A Simple Approach to the Management of Endowments,' All About Alpha, 2017, http://www.allaboutalpha. com/blog/2017/08/07/a-simple-approach-to-the-management-ofendowments/, accessed on 19 October 2018.

Ibn 'Ābidīn, Muḥammad Amīn, Radd al-Muhtār 'ala al-Durr al-Mukhtār Sharh Tanwīr al-Abṣār, vol. 6 (Bayrūt: Dār al-Ma'rifah, 2000).

Ibn Kathīr, Abū Fidā’ Ismā'il Ibn 'Umar, al-Qurshī al-Damashq̄̄, Tafsīr alQur'ān al-'Azīm, vol. 2 (Riyāụ: Dār Taybah li al-Nashr wa al-Tawzī', 2009).

Ibn Mājah, Abū 'Abd Allāh Muḥammad Ibn Yazid al-Qazwin̄i, Sunan Ibn Mājah, vol. 2 (Bayrūt: Dār Iḥyā' al-Kutub al-'Arabiyah, 1975).

Ibn Qudāmah, Abī Muḥammad 'Abd Allāh Ibn Aḥmad Ibn Muḥammad alMaqdisī, al-Mughnī, vol. 8 (Qāhirah: Hajr, 1992).

J. W. Brodman, Charity \& Religion in Medieval Europe (United States of America: The Catholic University of America Press, 2009).

James J. Fishman, 'What Went Wrong: Prudent Management of Endowment Funds and Imprudent Endowment Investing Policies,' The Journal of College and University Law, vol. 40/2 (2014): 199-246.

Jeffrey R. Brown, Stephen G. Dimmock, Jun-Koo Kang, \& Scott J. Weisbenner, 'How University Endowments Respond to Financial Market Shocks: Evidence and Implications,' American Economic Review, vol. 104/3 (2014): 931-62.

Al-Kasānī, Abū Bakr Ibn Mas'ūd al-Hanāfî, Baḍ̄ 'i ‘ al-Sana 'i' fì Tartīb alSharā'i', vol. 8 (Bayrūt: Dār al-Kutub al-'Ilmiyyah, 2003).

Malcolm Getz, 'Endowment,' The Bottom Line, vol. 4/2 (2007): 37-41.

Mehdi Madanchi, Shadi Shahverdiani, \& Fatemah Hamidifar, 'Endowment and Charity Financing Model to Develop Science and Technology,' International Journal of Finance and Managerial Accounting, vol. 1/4 (2016): 55-70.

Michael Lwin \& Ian Phau, 'Characteristics of Charitable Donors in Australia,' in Recent Advances in Retailing and Services Science Conference, ed. H. Timmermans (Istanbul, Turkey: Recent Advances in Retailing and Services Science, 2010), 1-22. 
Mohd Isa Rohayati, Youhanna Najdi, \& John C. Williamson, 'Philanthropic Fundraising of Higher Education Institutions: A Review of the Malaysian and Australian Perspectives,' Sustainability, vol. 8/ 541 (2016): 1-20.

Molly F. Sherlock, Jane G. Gravelle, Margot L. Crandall-Hollick, \& Jeffrey M. Stupak, 'College and University Endowments: Overview and Tax Policy Options,' Congressional Research Service, 2015.

NationalAssociation of College and University Business Officers, Commonfund Study of Endowments (Washington, D.C.: NACUBO, 2017).

Al-Nasā'̀', Sunan al-Nasā' '̄: Bi Sharh al-Hafiz Jalāl al-Dīn al-Ṣuyūṭ̄, vol. 5 (Bayrūt: Dār al-Kitāb al-'Alamiyah, n.d.).

Nasrul Hisyam Nor Muhamad, Mohd Arafat Jaafar, Muhibbuddin Abdullah, Nurul Atikah Nizaludin, Mohd Muslim Salleh, \& Mohd Muammar Mohd Zin, 'Konsep Maqasid Syariah dalam Pengurusan Wakaf,' International Journal of Islamic and Civilizational Studies, vol. 2/3 (2015): 1-9.

Al-Nawawī, Ab̄̄ Zakariyyā Maḥy al-Dīn Ibn Sharf, al-Majmū' Sharh alMuhadhdhab li al-Shirāzī, vol. 16 (Jeddah: Maktabah al-Irshād, 1980).

Al-Nawawī, Ab̄̄ Zakariyyā Maḥy al-Dīn Ibn Sharf, Sharh Saḥ̄ḥ Muslim bi Sharh al-Imām Muhyy al-Dīn al-Nawawī, vol. 11 (Bayrūt: Dār alMa'rifah, 2005).

Nazị̣ Hammād, Mu 'jam al-Muștalahāt al-Iqtiṣādiyyah fì Lughah al-Fuqahā' (Riyāẹ: Dār al-'Alamiyyah li al-Kitāb al-Islāmī, 1995).

Niẓām, al-Fatawā al-Hindiyah, vol. 2 (Bayrūt: Dār al-Kutub al-'Ilmiyyah, 2000).

Panduan Pengurusan Wakaf Institusi Pendidikan (Putrajaya: Jabatan Wakaf, Zakat dan Haji (JAWHAR), 2018).

Al-Qurțūbī, Abī Wālid Muḥammad Ibn Aḥmad Ibn Muḥammad Ibn Aḥmad Ibn Rushd, al-Jāmi ' li Aḥkām al-Qur'ān, vol. 5 (Bayrūt: Al-Risālah Publishers, 2006).

Al-Rahaybanī, M. S., Mațālib Uli al-Nuhā fì Sharh Ghayah al-Muntahā, vol. 6 (n.p.: n.p., 2000).

René Bekkers, 'Traditional and Health-Related Philanthropy: The Role of Resources and Personality,' Social Psychology Quarterly, vol. 69/4 (2006): 349-366.

Robert Louie Stanton McElhaney, 'The Effects of Higher Education Endowment Management Practices on Endowment Performance' (Ph.D. Thesis, The University of Southern Mississippi, 2010). 
Ronald G. Ehrenberg, 'Demystifying Endowments,' 2009, See http:// digitalcommons.ilr.cornell.edu/workingpapers/132/\%0ARequired, accessed on 9 March 2020.

Al-Sarakhsī, Abū Bakr Muḥammad Shams al-Dīn, al-Mabsūṭ, vol. 12 (Bayrūt: Dār al-Ma'rifah, 1989).

Al-Sarakhs̄i, Abū Bakr Muhammad Shams al-Dīn, al-Mabsūṭ, vol. 12 (Bayrūt: Dār al-Kitāb al-'Alamiyah, 2001).

Sergey Sazonov, Ekaterina Kharlamova, Irina Chekhovskaya, \& Elena Polyanskaya, 'Funds on the Basis of Mathematical Models Mechanism of Determination of Effectiveness of Spending Assets of Endowment Funds on the Basis of Mathematical Models,' International Journal of Educational Management, vol. 31/1 (2017): 21-29.

Al-Sharbīn̄i, Shams al-Dīn Muḥammad Ibn Muḥammad al-Khāțib, Mughnī al-Muḥtāj ilā Ma 'rifātī Ma 'ānì Alfāz al-Minhāj, vol. 2 (Bayrūt: Dār alMa'rifah, 1997).

Siti Mashitoh Mahamood, Asmak Ab Rahman, \& Aziz Che Seman, 'Pembentukan Institusi Pengajian Tinggi Berteraskan Wakaf di Malaysia: Cadangan Model Pelaksanaannya,' Jurnal Syariah, vol. 26/1 (2018): 1-22.

Siti Mashitoh Mahamood, Asmak Ab. Rahman, \& Azizi Che Seman, 'Cabaran Pelaksanaan Wakaf Universiti Awam di Malaysia: Analisis Menurut Perundangan di Malaysia,' Kanun, vol. 30/2 (2018): 383-409.

Stephen G. Dimmock, 'Background Risk and University Endowment Funds,' The Review of Economics and Statistics, vol. 94/3 (2012): 789-799.

Al-Ṭabarī, Abū Ja'far Muhammad Ibn Jarīr, Jamī' al-Bayān 'an Ta'wīl alQur'ān, vol. 3 (n.p.: Maktabah Mușțafā al-Bābī al-Ḥalābī, 1968).

Tawfique al-Mubarak, 'The Maqasid of Zakah and Awqaf and Their Roles in Inclusive Finance,' Islam and Civilisational Renewal, vol. 7/2 (2016): 217-230.

The New International Webster's Comprehensive Dictionary of The English Language, Deluxe Enc (Naples, Florida: Trident Press International, 1996).

The University Transformation Programme (UniTP) Purple Book: Enhanching University Income Generation, Endowment \& Waqf (Putrajaya: Kementerian Pendidikan Tinggi Malaysia, 2016).

Thomas Gilbert \& Christopher Hrdlicka, 'Why Are University Endowments Large and Risky?' The Review of Financial Studies (2015): 1-44. 
Al-Tirmidhī, Abū 'Īsā Muhammad Ibn 'Īsā Ibn Sawrah Ibn Mūsā, al-Jāmi ' al-Ṣaḥ̄h wa Huwa Sunan al-Tirmidhī, vol. 3 (Bayrūt: Dār al-Kitāb al'Alamiyah, n.d.).

Yu-Kang Lee \& Chun-Tuan Chang, 'Who Gives What to Charity? Characteristics Affecting Donation Behavior,' Social Behavior and Personality, vol. 35/9 (2007): 1173-1180.

Zaki Halim Mubarok, 'Peranan Wakaf dalam Membangun Identitas Muslim Singapura,' Jurnal Al-Awqaf, vol. 7/1 (2014): 1-22.

Al-Zuhaylī, Wahbah, al-Fiqh al-Islāmī wa Adillatuh, vol. 8 (Dimashq: Dār al-Fikr, 2010).

\section{Statutes}

Civil Law Act 1956 (Act 67), 2006.

Trustee Act 1949 (Act 208), 2016.

Universities and University Colleges Act 1971 (Act 30), 2012.

Wakaf (State of Selangor) Enactment 2015.

\section{Interviews}

Mohamad Afizal Mehat (Senior Assistant Director, Department of Higher Education (Malaysia), Public HEI Governance Division), data gained through e-mail, 9 February 2020. 